\title{
A New Dawn? Statelessness and Assam
}

Regina Menachery Paulose*

DOI: $10.21827 / 5 \mathrm{~d} 5141 \mathrm{~d} 9 \mathrm{ebe} 6 \mathrm{a}$

\section{Keywords}

ASSAM; STATELESSNESS; GENOCIDE; WARNING SIGNS; INDIA

\begin{abstract}
This article explores the ongoing crisis of statelessness that has been created because of a petition made by the people of Assam, India to update the electoral rolls in the state. As a result of the process, which has been approved by the Supreme Court of India, an estimated 4 million people have become stateless. The government has stated that these 4 million people risk deportation back to Bangladesh. This article will briefly examine the history of the situation that has unfolded in Assam; discuss the role of statelessness and how it may lead to genocide, underscoring the importance to act and find robust solutions. Finally, the author will conclude by discussing potential actions that India should take in order to resolve future cases of statelessness, specifically examining the Global Compact on Refugees and other instruments provided for within international refugee law.
\end{abstract}

\section{Introduction: Citizenship in Assam}

The state in northeastern India, Assam, enjoys a diverse, complex, and rich history. In 1950, three years after Indian independence, both leaders of Pakistan and India, in response to communal violence in Assam and Tripura wrote the Nehru - Liaquat Ali Khan Agreement and assured minorities that 'there shall be freedom of movement and protection in transit. ${ }^{1}$ In 1951, a National Register of Citizens (NRC) was prepared and created following the 1951 census. $^{2}$ The names of the people on this list qualified as citizens and were eligible to vote in elections. Four years later the Indian Parliament enacted the Citizenship Act which determined how India's citizenship was determined and acquired. 'In 1964, the Prevention of Infiltration from Pakistan Act was passed, and a special Border Police Force was raised '3 and between April and June 1965, India and Pakistan went to war over Kashmir. ${ }^{4}$

Attorney, International Criminal Law and Human Rights. J.D. Seattle University School of Law (2004), LLM International Crime and Justice, University of Turin, Italy (2012).

Nehru -Liaquat Ali Khan Agreement (8 April 1950).

Office of the State Coordinator of the National Register (NRC), 'National Register of Citizens' Government of Assam <http://www.nrcassam.nic.in/faq01.html> accessed 29 June 2019.

Nandita Saikia and others, 'Trends in immigration from Bangladesh to Assam, 1951-2001: Evidence from Direct and Indirect Demographic Estimation' (2016) Zakir Husain Centre for Educational Studies IMDS Project 5.

4 Aviral Virk, 'Who Really Won the India-Pakistan 1965 War?' (2018) The Quint $<$ https://www.thequint.com/news/india/who-really-won-the-india-pakistan-1965-war> accessed 29 June 2019. 
In 1971, the violent birth of Bangladesh caused over 5 million refugees to seek safety within India because of internal unrest within Pakistan that resulted in genocide and crimes against humanity. ${ }^{5}$ The civil war between East and West Pakistan resulted in a war between India and Pakistan. By 1972 after the war between India and Pakistan concluded, reportedly close to 6.8 million refugees returned to Bangladesh. ${ }^{6}$ Under the Indira-Mujib Treaty which came into effect after the war concluded, India agreed that all migrants who entered India on or before March 24, 1971 would not be considered 'de facto illegal."

By 1978, many Assamese protested the fact that non-citizens were given the right to vote in the state elections. ${ }^{8}$ As a result, various factions formed - the most notable - the All Assam Students Union (AASU) in 1979. These factions began protests that led to what was called the Assam Movement, and they 'set out to demand that the Indian State take concrete measures to stop the illegal influx' of immigrants. ${ }^{9}$ Although the Movement was non-violent in nature, it became riddled with violence. ${ }^{10}$ While the Movement continued, the 1981 census was cancelled. ${ }^{11}$ As the Movement progressed in the 1980's ethnic clashes were continually reported, and the instability of the Assamese government did not help matters. ${ }^{12}$ In 1983, the Government of India decided to hold state elections in Assam, despite the continued flare up of anti-foreigner sentiment. The government utilized the same electoral rolls that the Movement challenged in the late 1970s. On February 18, 1983, ethnic violence described as the 'Hobbesian war of all against all' erupted and unofficial estimates state 3,000 people were killed during the 'Nellie Massacre. ${ }^{13}$ In response to the petitions of the Movement and the violence, in December 1983 the Indian parliament enacted the Illegal Migrants (Determination by Tribunals) Act (IMDT) for the state of Assam. ${ }^{14}$ The IMDT allowed citizens within Assam to challenge the status of those who may be foreigners or illegal migrants. ${ }^{15}$

After the Nellie Massacre, the Government of India under the leadership of Rajiv Gandhi pursued options for peace in Assam, which led to the creation of the Assam Accords. The Assam Accords included several provisions, but the most relevant one stipulated:

Aasha Khosa, 'How India responded to the influx of 10 million refugees' (2015) Governance Now $<$ https://www.governancenow.com/news/regular-story/how-india-responded-the-influx-10-millionrefugees $>$ accessed 29 June 2019.

ibid.

Hiranya Nath and Suresh Nath, 'Illegal Migration into Assam: Magnitude, Causes, and Economic Consequences' (2011) SSRN Electronic Journal <http://dx.doi.org/10.2139/ssrn.1750383> accessed 29 June 201910. Sanjib Baruah, India Against Itself: Assam and the Politics of Nationality (University of Pennsylvania Press 1999) 115 and 121. Uddipana Goswami, Conflict and Reconciliation (Routledge 2014) 6.

See Nandana Dutta, Questions of Identity in Assam: Location, Migration, Hybridity (Age Publications 2012). Sanjib Baruah, 'The Partition's long shadow: the ambiguities of citizenship in Assam, India' (2009) 13(6) Citizenship Studies 593, 593. Quint <https://www.thequint.com/explainers/nellie-massacre-explained> accessed 29 June 2019. Baruah (n 8) 132.

The Illegal Migrants (Determination by Tribunals) Act (1983) No $39<$ <ttp://www.india-eumigration.eu/media/legalmodule/Illegal\%20Migrants\%20Act\%201983.pdf> accessed 29 June 2019. The Illegal Migrants (Determination by Tribunals) Act (n 14) para 8. 
Illegal aliens who had entered the state between January 1966 and March 1971 would be disenfranchised for ten years and those who came after March 1971 would be deported. It was agreed that the state government formed after the election of 1983 would resign, the state assembly would be dissolved, and fresh elections based on revised electoral rolls would take place in December $1985 .{ }^{16}$

India also amended the aforementioned Citizenship Act to reflect what was agreed upon in the Assam Accords. ${ }^{17}$ While the office to implement the Assam Accords was created in 1985, the process has continued to be slow. Triparate meetings were held in 2005. The AASU appeared positive about conversations that took place about border security and an update to the NRC. ${ }^{18}$ The AASU's demand to scrap the IMDT was denied. However, not long after the Supreme Court of India struck down the IMDT. ${ }^{19}$ Therefore, the governing law to be used as stipulated by the Supreme Court was the 1950 Immigrants (Expulsion from Assam) Act, together with the 1946 Foreigners Act and the Foreigners Tribunal Order of 1964. The Foreigners Act gives the state government authority to regulate or restrict entry of foreigners. This also means that the state authority may determine how people are deported. It is then that the Foreigners Tribunal provides a 'reasonable opportunity' for the person accused of being a foreigner to represent themselves and produce evidence in support of their case for citizenship. ${ }^{20}$

One of the turning points of the situation in Assam was litigation filed in 2009 by a nonprofit organization called Assam Public Works (APW). APW filed a petition against the Union of India to 'delete the names of illegal migrants from voters' lists in Assam and updat[e] the NRC. ${ }^{21}$ The Supreme Court of India responded by taking up leadership in ensuring the NRC would be updated in subsequent cases. Since 2014, the Supreme Court has monitored progress to ensure the terms laid out in its orders are met. The drafts of the registry continue to be published. Concerns have been raised by the first draft which omitted the names of several families. ${ }^{22}$ Some of concerns expressed related to corruption in the process, the specific targeting of impoverished people during citizen sweeps, and disregard of documentation provided by people. ${ }^{23}$ As of July 2018, the draft excluded approximately 4 million people from the NRC list. These people will become stateless if they lose during the appeals process. As of 1 November 2018, the Indian Supreme Court allowed 5 more additional documents to be utilized to determine whether a person was an Indian citizen

\footnotetext{
Baruah (n 8) 139.

ibid.

'Review of Assam Accord fruitful: AASU' (2005) The Hindu <https://www.thehindu.com/2005/05/08/stories/2005050813281000.htm> accessed 29 June 2019.

See Anupama Roy and Ujjwal Kumar Singh, 'The Ambivalence of Citizenship' (2009) 41(1) Critical Asian Studies 37.

Foreigners (Tribunals) Order 1964 (23 September 1964) para 3.

Assam Public Works v The Union of India (Writ Petition (Civil)) (2018) No 274/2009.

Dr. Pushpita Das, 'Publication of the National Register of Citizens: a positive step, but what next'(2018) Institute for Defence Studies and Analyses <https://idsa.in/idsacomments/publication-of-the-nationalregister-of-citizens_pdas_040118> accessed 29 June 2019. accessed 29 June 2019.
} 
or not. The Court has appeared to set a final deadline for challenges for December 15, $2018 .^{24}$

What is supposed to be separate but appears to have become conflated ${ }^{25}$ with the NRC issue is the Foreigners Tribunals. ${ }^{26}$ These Tribunals have been set up to detect and deport foreigners. ${ }^{27}$ However, the reason for conflating both processes may be easily understood as those who are excluded from the NRC list are classified as "D" voters and are sent to Foreigners Tribunals, set up throughout Assam, which in turn determine whether they are to be deported. ${ }^{28}$ The Supreme Court has delegated the Gauhati High Cour $^{29}$ to monitor these tribunals, which face their own criticism for being unprofessional.

The Supreme Court of India also ordered negotiations to take place with Bangladesh to deport those who are declared foreigners back to Bangladesh. Bangladesh has not acknowledged that the deportees are Bangladeshi citizens. So far, most of the people who have not been able to authenticate their citizenship based on the poor standards have found themselves detained in overcrowded jails. ${ }^{30}$ The Government of Assam is in the process of expanding construction of detention facilities to hold more people. ${ }^{31}$ Sadly, the NRC process appears to have created an atmosphere of violence that is worse than in the 1980s. ${ }^{32}$ Unfortunately, given the confusion over the NRC, and the upcoming Lok Sobha elections, history will not be instructive but repetitive.

While this process has been ongoing, the possible deportations of alleged foreigners have not placated groups. The Citizenship Bill (2016), which would amend the Citizenship Act, seeks to grant citizenship to many minority groups who reside in India and in turn has raised the ire of many people, including those in Assam. ${ }^{33}$ The Supreme Court in the

PTI, 'High-level panel to chalk out plans on fate of people left out of final NRC in Assam' (2018) LiveMint $<$ https://www.livemint.com/Politics/bJUh0TMdo3OODznBwHSJNI/Highlevel-panel-to-chalk-outplans-on-fate-of-people-left-o.html> accessed 29 June 2019.

Ipsita Chakravarty, "Assam has received sanction from Centre to build a detention camp for "foreigners"' (2018) Scroll.in <https://scroll.in/article/887351/assam-has-received-sanction-from-centre-to-build-adetention-camp-for-foreigners> accessed 29 June 2019.

For more information on the Tribunals see Government of Assam 'Foreigners Tribunal' $<$ https://homeandpolitical.assam.gov.in/portlets/foreigners-tribunal> accessed 29 June 2019.

It should be noted that consistent throughout Indian scholarship is the fact that it is nearly impossible to determine the actual amount of "illegal migrants" or "foreigners" as I will later discuss in this article. Nath (n 7).

'India: Assam's Citizen Identification Can Exclude 4 Million People' (2018) Human Rights Watch $<$ https://www.hrw.org/news/2018/07/31/india-assams-citizen-identification-can-exclude-4-millionpeople> accessed 29 June 2019.

Assam Sanmilita Mahasangha \& Others (Petitioners) versus Union of India \& Others (Respondents) (Writ Petition (Civil)) (2012) No. 562 <http://nrcassam.nic.in/images/pdf/01.pdf> accessed 29 June 2019, 67.

Bikash Singh 'Centre sanctions detention camp for "foreigners" in Assam' (2018) The Economic Times $<$ https://economictimes.indiatimes.com/news/politics-and-nation/centre-sanctions-detention-camp-forforeigners-in-assam/articleshow/65083124.cms> accessed 29 June 2019.

Chakravarty (n 18).

Debarshi Das, 'Today's Assam Looks More and More Like the Violence 1980's' (2018) The Wire $<$ https://thewire.in/rights/assam-violence-nrc-polarisation> accessed 29 June 2019.

PTI, 'AASU 28 other student bodies in Assam announce protests against Citizenship Bill' (2018) The Week <https://www.theweek.in/wire-updates/national/2018/10/31/cal7-as-citizenship-protests.html> accessed 29 June 2019. 
meantime chastised the Assam government for "inaction against the detected illegal immigrants and those in detention centres." ${ }^{34}$

\section{The Status Quo and Statelessness}

It is important to remember that India is not a party to the 1951 Refugee Convention or accompanying protocols. Despite this, the United Nations Refugee Agency (UNHCR) operates in different parts of the country and assists with the influx of refugees where it is permitted to do so. ${ }^{35}$ One of the greatest challenges, it appears, is under Indian law where 'the term foreigner is used to cover aliens temporarily or permanently residing in the country. This places refugees, along with immigrants, and tourists in this broad category. ${ }^{36}$

Under the 1954 Convention on Statelessness ('Statelessness Convention'), a stateless person is defined as someone who 'is not considered as a national by any State under the operation of its law. ${ }^{37}$ In 1961 the United Nations adopted the Convention on the Reduction of Statelessness ('1961 Convention'). The 1961 Convention, as will be discussed later, 'sets rules for the conferral and non-withdrawal of citizenship to prevent cases of statelessness from arising. ${ }^{38}$

India has not ratified relevant international treaties including United Nations 1951 Convention Relating to the Status of Refugees ('Refugee Convention') or the Statelessness Convention. ${ }^{39}$ India has a duty under customary international law and its treaty obligations to prohibit arbitrary deprivation of nationality, to avoid non-discrimination in matters pertaining to nationality, and to avoid statelessness. ${ }^{40}$ This duty to not deprive people of nationality is particularly emphasized in the Universal Declaration of Human Rights in Article 15.

Within the Indian national system, the Indian Constitution and the Citizenship Act guard the parameters regarding citizenship. The Citizenship Act is complemented by the Citizenship Rules, which are the rules of procedure. The Citizenship Act allows people to

Bidisha Barman, 'In Assam's Mangaldoi, struggle to get listed on NRC emerges as major poll issue; Muslims determined to vote in large numbers' (2019) FirstPost < https://www.firstpost.com/politics/in-assamsmangaldoi-struggle-to-get-listed-on-nrc-emerges-as-major-poll-issue-muslims-determined-to-vote-in-largenumbers-6289511.html> accessed 29 June 2019.

Rina Chandran, 'Poverty and politics trip up urban refugees in India' (2018) Reuters $<$ https://www.reuters.com/article/us-india-refugees-rights/poverty-and-politics-trip-up-urban-refugees-inindia-idUSKBN1IC001> accessed 29 June 2019; United Nations High Commissioner for Refugees, 'India' (2011) UNHCR Global Appeal 2011 <https://www.unhcr.org/4cd96e919.pdf> accessed 29 June 2019.

Arjun Nair, 'National Refugee Law for India: Benefits and Roadblocks' (2007) 11 Institute of Peace and Conflict Studies <http://www.ipcs.org/issue_briefs/issue_brief_pdf/51462796IPCS-ResearchPaper11ArjunNair.pdf> accessed 29 June 2019.

Convention Relating to the Status of Stateless Persons (adopted 28 September 1954, entered into force 6 June 1960), art 1(1).

Convention on the Reduction of Statelessness, (adopted 30 August 1961, entered into force 13 December 1975) 3.

While India has not signed these treaties, it has since 1995 been a member of the UNHCR Executive Committee and Executive Committee member of the International Office of Migration since 2008. Sanjeev Tripathi, 'Illegal Immigration from Bangladesh to India: Toward a Comprehensive Solution' (2016) Carnegie India <https://carnegieindia.org/2016/06/29/illegal-immigration-from-bangladesh-to-india-towardcomprehensive-solution-pub-63931> accessed 29 June 2019.

Alice Edwards, 'The meaning of nationality in international law in an era of human rights' in Alice Edwards and Laura Van Wass (eds), Nationality and Statelessness (CUP 2015) 25. 
obtain citizenship through 'registration' unless one is an 'illegal migrant,' thereby disqualifying them from this particular process. ${ }^{41}$ The Citizenship Act has two sections relating to termination and deprivation of citizenship, but contains no procedure to prevent statelessness. ${ }^{42}$

Based on the lack of protection for stateless people in the national laws, it comes as no surprise that the Assam government would promote a policy option of statelessness. However, it is also clear that the situation in Assam was not created overnight, and many variables have caused this perilous situation to be ripe for creating a large stateless population and continued human rights violations to continue.

It appears the status quo NRC issue was created by three overarching variables: (1) the lack of legitimate demographic information; (2) ethnic violence; and (3) hate speech by political parties. These three variables all intertwine with each other to have created a policy choice that revocation of citizenship is the only way to respond to perceived threats from illegal immigration.

\section{Lack of Information}

An examination is warranted as to whether the information that is constantly recycled through political forces is accurate. The Assam government did not update the NRC annually. ${ }^{43}$ Given the disturbances there was no census taken in Assam in 1981. The next censuses were taken in 1991, 2001, and 2011 respectively. These censuses do not substantiate any of the claims of the numbers of 'foreigners' present in Assam. ${ }^{44}$ The census report analysts appear only to make conjectures that an influx of immigration ${ }^{45}$ is the reason why the census reflects a growing Muslim population demographic. None of the census reports or other instruments reflects how illegal populations of people have been identified or calculated. This is perhaps because India's Census Act, 'fails to provide basic clarifications regarding who are to be counted under census exercises, and the grounds required in order to be counted as part of the population, (i.e. being a citizen or a noncitizen). ${ }^{46}$

In addition, it appears in most demographic analysis completed by scholars after 1991, most of them add the concern that the Hindu population could become a minority in the state of Assam, when in fact a multitude of variables may be causing that concern, such as low birth rates among Hindus, religious conversions, and migration due to a lack of employment opportunities. ${ }^{47}$ The AASU has continually repeated that updating the NRC

Sitharamam Kakarala, India and the Challenge of Statelessness: A Review of the Legal Framework Relating to Nationality (National Law University Delhi Press 2012) 37.

ibid 46.

R. Dutta Choudhury, 'Regular NRC update would have checked influx: AASU' (2017) The Assam Tribune <http://www.assamtribune.com/scripts/detailsnew.asp?id=nov2917/at057> accessed 23 June 2019.

Sanjoy Hazarika, 'Defining Citzenship: Assam on the Edge Again' (2018) Economic and Political Weekly 1. See also Nath (n 7).

Dr Bhupen Kumar Nath and Dilip C Nath, 'The Change in Religion and Language Composition in the State of Assam and in Northeast India: A Statistical Analysis since 1951 to 2001' (2012) 2(5) International Journal of Scientific and Research Publications 1.

ibid 48.

One such example is Dibya Jyoti Kalita's paper which rings the alarm bells in the conclusion; Dibya Kalita, 'Migration and Population Growth in Assam: a District Level Study' (2015) 356-368. 
has nothing to do with religion, but its purpose is to address illegal immigration from Bangladesh. ${ }^{48}$ Researchers state that the 2001 census results indicated a 5.39 percent decline in the growth of Assam's population. ${ }^{49}$ Further, according to the tally prepared by the Assamese state government during its operation phase from $1985-2005$, the IMDT managed to deport a total of 1,547 people out of 112,791 referred cases..$^{50}$ The numbers do not come close to matching the numbers that are continually used to claim there is a problem of illegal migrants in Assam. Sanjoy Hazarika, International Director of the Commonwealth Human Rights Initiative notes, 'studies are needed on either side of the border to look at diminishing and growing populations in villages and districts, driven by migration. ${ }^{51}$

\section{Ethnic Tensions}

Prior and subsequent to the Nellie Massacre, ethnic violence has continued to occur in Assam, particularly with the Bodo movement calling for a separate state called Bodoland. The ethnic clashes have been grotesque. As one journalist reported:

In October 1993, Bodo-Muslim clashes affected around 4,000 families in Kokrajhar and Bongaigaon, in 1994, 113 were killed in Barpeta; Bodo-Adivasi clashes in 1996 and 1998 saw almost 400 people killed and over 3 lakh displaced; again in 2008, Bodo-Muslim clashes left 65 killed and over 2 lakh displaced. Similarly, Karbi-Kuki clashes in Karbi-Anglong in 2003-04 saw 98 killed and some 11,000 displaced; Karbi-Dimasa clashes in 2005 led to 103 deaths and nearly 50,000 being displaced. ${ }^{52}$

This of course does not include the bombings in 2008 and 2014. ${ }^{53}$ Also during this time period there was a flare up in violence between the Bodos and Muslim population in 2012 which killed approximately 60 people and displaced over $150,000 .^{54}$ The Bodo leaders state that resource scarcity is one of the main reasons that they conduct 'ethnic cleansing' and strive to have a home state like that of Israel. ${ }^{55}$ The Bodos also attribute these problems to illegal immigrants from Bangladesh. Although the demographic data is neither studied nor researched to identify what are the true causes of scarcity, this scarcity and anti-immigrant platform has mobilized the Bodos and other groups.

Karishma Hasnat, 'Assam Students Union vows to Provide Legal Help to 'Indians' Caught in NRC Tangle' (2018) News18 <https://www.news18.com/news/india/assam-students-union-vows-to-provide-legal-helpto-indians-caught-in-nrc-tangle-1804669.html> accessed 29 June 2019.

'Census shows drop in Assam population' (2001) The Hindu <https://www.thehindu.com/thehindu/2001/03/30/stories/1430203e.htm> accessed 29 June 2019.

'White Paper on Foreigners Issue' (May 2015) Assam Government Home and Political Department <https://assam.gov.in/web/home-and-political-department/white-paper1\#23> accessed 12 May 2019, 2.3.2.

Hazarika (n 20) 2.

TNN, 'A distraught tribal: The genesis of Assam ethnic violence' (2012) The Economic Times $<$ https://economictimes.indiatimes.com/news/politics-and-nation/a-distraught-tribal-the-genesis-ofassam-ethnic-violence/articleshow/15458830.cms> accessed 29 June 2019.

Nilim Dutta, 'India's 'other' war: Jihadi paranoia and ethnic militancy' (2015) DAWN <https://www.dawn.com/news/1164657> accessed 29 June 2019.

Samrat, 'Violence in Assam has Deep Roots' (2012) New York Times <https://india.blogs.nytimes.com/2012/07/26/violence-in-assam-has-deep-roots/> accessed 29 June 2019.

ibid. 
Another factor contributing to the violence is the activities of the United Liberation Front of Asom (ULFA), which was formed in 1979 to create an independent socialist Assam. The ULFA's support waned after the end of the Movement, but since 1990, at the very least, been deemed a terrorist organization. ULFA has blamed 'illegal migrants' for 'creating a chaotic situation and threatening Assam's existence. ${ }^{56}$ The group also wants to expel the Indian army as well those who are considered illegal migrants. Recently ULFA launched a recruitment drive to increase its numbers in order to continue its efforts to create an independent Assam. ${ }^{57}$ The anti-immigrant sentiment appears to be a rallying point for groups to justify or continue violence.

\section{Politics and Hate}

Given the lack of credible information and the ethnic tensions in Assam, it is no surprise that political factions in the Assamese government and national Indian government have capitalized on anti-foreigner rhetoric and amassed political support for their parties in one way or another. On the local level, since 1915 the government of Assam has been consistently vocal that Muslim immigration from Bangladesh (and Bengal prior to that) has been a problem. ${ }^{58}$ It was Assamese Governor S.K. Sinha's report in 1998, which stated, 'as a result of population movement from Bangladesh, the spectre looms large of the indigenous people of Assam being reduced to a minority in their home state' that has continued to be repeated and cited as a basis for action. Sinha erected a fence along the shared border with Bangladesh and subsequently the Bharatiya Janata Party (BJP) 'began to warn of a "Muslim Avalanche from Bangladesh" repeating fear narratives for several electoral cycles. ${ }^{59}$ It appears that most of this rhetoric is aimed at disenfranchising a large voting population or 'vote banks' of Muslims who appear to be the majority in Assam. ${ }^{60}$ However, research conducted by the Centre for Policy Research focusing on Assam elections and voting patterns concluded:

The large Muslim population has become central to any electoral understanding of Assam. Yet, as we have argued here, Muslim politics in Assam is quite complex, if not fractured. There is no consolidated Muslim vote bank, nor is it necessarily meaningful to consider such a possibility. The Muslims are still far from a kingmaker in Assam. ${ }^{61}$

Rizwana Shamshad, Bangladeshi Migrants in India: Foreigners, Refugees, or Infiltrators? (Oxford University Press 2017).

Rajeev Bhattacharyya, 'ULFA goes on a recruitment overdrive in Assam as outlawed group's cadre strength thins out' (2017) FirstPost <https://www.firstpost.com/india/ulfa-goes-on-a-recruitment-overdrive-inassam-as-outlawed-groups-cadre-strength-thins-out-3505511.html> accessed 29 June 2019.

Chandan Kumar Sharma, 'Immigration, indigeneity and identity' in Dilip Gogoi (ed), Unheeded Hinterland: Identity and Sovereignty in Northeast India (Routledge 2016) 92.

Kristin Hoelscher and Jason Milkian, "The violence of migration from Bangladesh to India" in Jason Miklian and Ashid Kolas (eds), India's Human Security: Lost Debates, Forgotten People, Intractable Challenges (Routledge, 2013).

The term "vote banks" were coined by M.N. Srinivas as "a population, usually a caste or religious identity group that trades its votes wholesale for patronage from a political candidate or party." Bhanu Joshi and others "Understanding the Election in Assam (Part 2)" Centre for Policy Research <http://cprindia.org/sites/default/files/working_papers/Understanding\%20the\%20election\%20in\%20Ass am\%20\%28Part2\%29.pdf> accessed 29 June 2019, 3.

Joshi (n 46) 7. 
In spite of this, the rhetoric is likely to continue because the BJP has identified Assam as a key area in the upcoming 2019 elections in the Lok Sabha. ${ }^{62}$ The rhetoric towards the four million that have been identified as non-citizens (despite clear evidence of irregularities with the process) has intensified and reached a new level of dehumanization. ${ }^{63}$ Sadly, this same fear mongering and anti-immigrant rhetoric is also used by the Supreme Court of India in its decisions involving Assam and the Citizenship laws. ${ }^{64}$ If the propaganda that foreigners are attempting to take over Assam or that Bangladesh is trying to usurp Assam into its territory were true, it would have happened by now ${ }^{65}$ given the radical numbers that continue to be repeated by those in Assam and in the BJP.

\section{From Statelessness to Genocide: Warning Signs?}

Before delving into the central question of this article, whether the Global Compact on Migrants and Refugees could provide relief for the situation in Assam, it is important to discuss the warning stages of genocide, which are present in Assam as a result of the NRC fiasco.

There are ten warning stages that indicate genocide is likely to occur. The ten stages of genocide are 'classification, symbolization, discrimination, dehumanization, organization, polarization, preparation, persecution, extermination, and denial. ${ }^{.66}$ The stages do not happen in a linear fashion and may happen simultaneously. The author notes that in the context of what is happening in Assam, and as discussed earlier, it is clear that at least five to six stages are currently present. ${ }^{67}$

Within the ten stages of genocide, rendering people stateless (de jure stateless) is likely to occur during two possible stages. The first is during the classification stage, which is defined as 'us versus them' and emphasizing the difference between peoples. In this stage, it is likely that rhetoric and behavior by the government or factions in civil society, calling for movement towards a policy that underscores this classification, will likely escalate. As discussed earlier in the article, this is already occurring on both the local level in Assam and on the national level through various members of the BJP. The second possible occurrence is during the discrimination stage, where statelessness is highly likely to occur because the

Naresh Mitra, "Want Assam rural polls to be held soon, says BJP" (2018) Times of India $<$ https://timesofindia.indiatimes.com/city/guwahati/want-assam-rural-polls-to-be-held-soon-saysbjp/articleshow/64916087.cms> accessed 29 June 2019.

Press Trust of India, "Bangladeshi migrants are termites, will be struck off voter list: Amit Shah" (2018) Business-Standard <https://www.business-standard.com/article/politics/bangladeshi-migrants-aretermites-will-be-struck-off-voter-list-amit-shah-118092200396_1.html> accessed 29 June 2019.

Referring to Assam Sanmilita Mahasangha \& Ors vs Union of India \& Ors (Writ Petition (Civil)) (2014) No 562 of 2012.

Anindita Dasgupta, 'The myth of Assamese Bangladeshi' (2018) HIMAL South Asian <http://himalmag.com/the-myth-of-the-assamese-bangladeshi/> accessed 29 June 2019.

Dr. Gregory Stanton, 'The Ten Stages of Genocide' (1996) Genocide Watch <http://www.genocidewatch.org/genocide/tenstagesofgenocide.html> accessed June 29 2019; this was originally written in 1996 at the U.S. Department of State as the 'Eight Stages of Genocide' presented at the Yale University Center for International and Area Studies in 1998 and revised in 2013.

The Common Good Foundation, 'Stateless in Assam: Precursors to Genocide and Crimes against Humanity?' (2018) Genocide Watch <http://docs.wixstatic.com/ugd/e5b74f_0abf14c4e86946d2bdb06572597ffca6.pdf> accessed 29 June 2019, paras 35-37. 
identified group in most cases loses their basic rights, such as citizenship. ${ }^{68}$ This has been evident from the application of the NRC process mainly towards the Muslim minority in Assam.

\section{The Global Compact on Migration and Refugees}

In 2016 the United Nations General Assembly (UNGA) adopted a political declaration, known as the New York Declaration to address and respond to the 'growing global phenomenon of refugees and migrants ${ }^{\prime 69}$ particularly through 'large movements.' The New York Declaration attempts to define 'large movements' as reflecting 'numbers of people arriving, economic, social, and geographic contexts, and the capacities of States to respond.' In addition large movements have 'political, economic, social, developmental, humanitarian, and human rights ramifications. ${ }^{70}$ The UNGA through the New York Declaration sought to address the root causes of large movements of refugees and migrants through 'increased efforts aimed at early prevention of crisis situations based on preventive diplomacy. ${ }^{71}$ The New York Declaration provided the initial framework for the 'Comprehensive Refugee Response Framework' (CRFF) which is an 'integral part ${ }^{72}$ of and informs both the Global Compact on Refugees (GCR) and the Global Compact on Migration (GCM). India supported and signed the New York Declaration. ${ }^{73}$

\section{Refugees}

Briefly, the CRFF makes four recommendations which include easing pressuring on host societies, encouraging and supporting refugee self-reliance, expanding third-country solutions, and supporting conditions in countries of origin for safe and dignified return. ${ }^{74}$ For successful implementation of the CRFF a mindset shift within the four areas identified. ${ }^{75}$ These recommendations are enveloped in the GCR, which like the GCM, is not legally binding. For the purposes of this article, it is important to focus specifically on the statelessness aspects of the GCR. The GCR is complimented by the statelessness conventions ${ }^{76}$ and the mandate holder of the GCR is the UNHCR. The GCR provides certain tools that may be of use to India, as a host country. The first tool of great importance would be collecting reliable data on those who are refugees and stateless people. ${ }^{77}$ This

Stanton (n 52).

United Nations General Assembly, 'New York Declaration for Refugees and Migrants' (13 September 2016)

A/71/L.1, para 2.

ibid para 6 and 7.

ibid para 12.

Report of the High Commissioner for Refugees, 'Part II Global Compact on Refugees' (September 13 2018)

A/73/12, para 10 .

Pallavi Saxena and Nayantara Raja, 'The imperative to offer refuge' (2018) The Hindu <https://www.thehindu.com/opinion/op-ed/the-imperative-to-offer-refuge/article24203930.ece> accessed 29 June 2019.

Randall Hansen, 'The Comprehensive Refugee Response Framework: A Commentary' (2018) 31(2) Journal of Refugee Studies 131.

Manisha Thomas, 'Turning the Comprehensive Refugee Response Framework into Reality' (2017) 69 FMR Review <https://www.fmreview.org/sites/fmr/files/FMRdownloads/en/latinamericacaribbean/thomas.pdf> accessed 29 June 2019.

Report of the High Commissioner for Refugees (n 71) para 5. ibid para 46. 
would be of benefit to India considering the data currently does not exist to support the arguments advanced by the Assamese and Indian government. Another tool outlined is the 'contribut[ion] of resources and expertise for the establishment of mechanisms for identification, screening and referral of those with specific needs to appropriate and accessible processes and procedures. ${ }^{78}$ This specifically includes procedures for statelessness. This is a critical resource not only because it may help India, but because it may bring about a decrease in human rights violations which are ongoing in the NRC process. For example, the Assam government is collecting biometric data for those who are appealing the decision of being placed on the NRC list and who have been identified as needing to be placed on the list. ${ }^{79}$ Further, many people who are in the camps have legitimate paperwork to prove that they should have the right to vote and are not 'foreigners.' 80

Other potential avenues to provide redress for host countries include the civil registries, encouraging countries to accede to the Conventions on Statelessness. India was part of the 181 countries who voted in favor of the GCR in December 2018 and part of the 152 countries who voted in favor of the GCM, which we now discuss. ${ }^{81}$ Perhaps the GCR will provide India with more resources on how to deal with statelessness and refugees, but the GCR much like its sister compact, will not be able to address the ethnic tensions and hate campaign hurdled towards alleged foreigners.

\section{Migrants}

The GCM contains 23 objectives for managing migration. These objectives include reducing vulnerabilities faced by migrants, collecting and utilizing data, eradicating trafficking in persons, and working towards a safe and dignified return and readmission for migrants. Given the context of the GCM it is not likely that this will provide any relief in the near term for the situation in Assam.

\section{The Way Forward?}

India's response to the events in Assam has reached a crossroads. On one hand, it must balance the protection of human rights for the over four million people likely to become stateless after the final publication of the NRC. On the other hand, it must consider the possibility that any perceived retractions have the possibility of igniting violence and polarizing groups within Assam even further. The Supreme Court's involvement in the process should have brought comfort that human rights and the prevention of mass atrocities would be a priority. Unfortunately, as this is not the case, it is highly unlikely that a petition could be made to the Court to stop the current process given all variables discussed earlier in this article. One significant push that could be made is to ask India's

ibid para 60.

'Biometric details lead to NRC confusion in Assam' (2019) NorthEast Now News < https://nenow.in/northeast-news/biometric-details-leads-to-nrc-confusion-in-assam.html> accessed 29 June 2019.

Chandrima Banerjee, 'Assam's refugees hope for return of citizenship bill' (2019) The Times of India $<$ https://timesofindia.indiatimes.com/city/guwahati/assams-refugees-hope-for-return-of-citizenshipbill/articleshow/68449043.cms> accessed 29 June 2019. 
Supreme Court to align its orders and the orders of the Guahati High Court with the 'Tunis Conclusions' during the appeals process for those that are excluded from the final NRC list.

The Tunis Conclusions recommendations, created as a result of roundtable discussions regarding the 1961 Convention on the Reduction of statelessness, ${ }^{82}$ specifically focused on loss and deprivations of citizenship, provide for certain interpretations on the 1954 Convention and could add balancing factors to the process in order to stave off statelessness and mass atrocities. The three largest elements that should be included are: 1) definitive standard for deprivation of citizenship; 2) non-discrimination; and 3) a legitimate and proportionate purpose.

Based on the reports that have been documented within Assam, it is clear that there is no clear or firm standard that identifies what constitutes deprivation of citizenship. ${ }^{83}$ The national laws of India appear to have exceptions carved out for the state of Assam. In one instance it may be that the laws of India without the Assam exceptions provide broader protections for those who are now stateless. Further, there is a risk some people may have been cleared through the IMDT process but are facing trial again through the Foreigner Tribunals. Corruption appears rampant based on civil society reports.

The second element focuses on preventing discrimination on the grounds of religion. ${ }^{84}$ Although many civil society organizations and the Courts themselves may state that this is not a policy directed towards a minority, the rhetoric from the national and the actions state government indicate otherwise. Recently a news report indicated that the names of some who are considered 'foreigners' appeared on the draft list for the NRC. ${ }^{85}$ The authorities in the State of Morigaon district have begun to delete these names. While this may seem innocent, a closer inspection reveals from the 2011 census the Muslims comprise the majority in the district..$^{86}$ Therefore it is important that the Supreme Court of India emphasize zero tolerance for discrimination towards particular religious groups and for the Courts within Assam to avoid tolerating this kind of discrimination.

The third element has two functions and asks two questions; does it serve a legitimate purpose and is it proportionate ${ }^{87} \mathrm{Of}$ all the elements, this is the most critical for India to evaluate as it has been consistently reported that the Foreigners Tribunals are not operating with appropriate judicial standards and revocation of citizenship has been arbitrary. The revocation of citizenship by those who have spent years in Assam working and have no ties to any other country serves no purpose except to placate groups who use hate speech as a means to become the majority. The revocation of citizenship is not proportionate considering the Citizenship Act allows for registration of those who have

'Interpreting the 1961 Statelessness Convention and Avoiding Statelessness resulting from Loss and Deprivation of Nationality' (2013) UNHCR <https://www.refworld.org/pdfid/533a754b4.pdf> accessed 29 June 2019.

'Interpreting the 1961 Statelessness Convention and Avoiding Statelessness resulting from Loss and Deprivation of Nationality' (2014) UNHCR (Tunis Conclusions) <http://www.refworld.org/docid/533a754b4.html> accessed June 29 2019, para 16. ibid para 18.

Prasanta Mazumdar, 'Declared foreigners, suspected foreigners make it to National Register of Citizens' (2018) India News Express <http://www.newindianexpress.com/nation/2018/aug/03/declaredforeigners-suspected-foreigners-make-it-to-national-register-of-citizens-1852746.html $>$ accessed 29 June 2019.

'Morigaon District: Census 2011 data' Census $2011<$ https://www.census2011.co.in/census/district/161morigaon.html> accessed 29 June 2019.

UNHCR Expert Meeting (n 63) paras 19-24. 


\section{GroJIL 7(1) (2019), 99-111}

been in India after a certain time period. Therefore, the national law provides a remedy for people whose paperwork may be dismissed by inconsistent standards.

It should be emphasized that while the warning signs are in place for statelessness and genocide to occur in Assam, it is not too late to change the course of direction. While there will be cases of statelessness based on variables at play on the national and local levels, adding the standards gleaned from the Tunis Conclusions may be one way to increase the quality of decisions made at the local level with regards to citizenship. In addition, civil society must continue its pressure to prevent India from creating havoc not only within the state of Assam but causing unnecessary tension between itself and Bangladesh.

\section{Conclusion}

Based on the historical events in Assam, it may be appropriate to suggest that statelessness is an inevitable policy choice given the lack of accurate information, the ethnic tensions, and the platform used by the government. In the case of Assam, the revocation of citizenship of millions of people will continue to have dire consequences because of the gaps within India's refugee laws and policies. Some of these laws, as explored above, are antiquated, as well as the motives behind some of the new policy regulations that are coming from the national and local legislatures.

The Global Compact on Refugees may bring some needed solutions in allowing India to march forward and lessen the amount of human rights violations that will snowball into genocide, given the warning signs that have appeared. The issue, by itself, is a complicated one to unpack, but that does not necessarily mean the solutions have to be as complicated. The Global Compact on Refugees offers some pathways for India to address the NRC issue in a humane and orderly way. However, in the short term the Tunis Conclusions may be a tool that the Supreme Court could utilize before the July 31, 2019 deadline for the NRC. 